\title{
Eero Ropo
}

\section{OPETTAJAEKSPERTTIYDEN KEHITTYMINEN}

- tutkimustuloksia ja näkökulmia

\author{
Yhdysvaltalainen David Berliner on kehitellyt opettaja- \\ eksperttiyden teoriaa nähden eksperttiyden kehittymisen \\ viisiportaisena. Ensimmäisenä vaiheena hänen luokituksessaan \\ on noviisi, viimeisenä ekspertti. Eero Ropo käsittelee \\ opettajaeksperttiyttä käyttäen pohjana Berlinerin luokitusta ja \\ edeten yhdeksän eksperttiyttä koskevan våittämän kautta.
}

\begin{abstract}
"Tähänastisesta tutkimuksesta voitaisiin poimia pitkä luettelo asioita tai ominaisuuksia, jotka näyttävät erottavan ekspertit ja noviisit. Erojen löytåminen on kuitenkin vain alku tutkimukselle. Erot on pystyttåvä myös tulkitsemaan teoreettisesti mielekkäällå ja tutkimusta ohjaavalla tavalla", hän kirjoittaa. Prosessit, jotka ovat johtaneet erojen syntymiseen, ovat kirjoittajan mukaan pääosin vielä tuntemattomia.
\end{abstract}

\section{YLEISTÅ}

Asiantuntijuuden, eksperttiyden, olemusta koskevan tutkimuksen alku voidaan sijoittaa 1960-luvulle, jolloin mm. de Groot (1965) tar. kasteli shakkimestareiden pelitaitoa ja pelin aikana tapahtuvaa informaation käsittelyä. Näissä tutkimuksissa osoitettiin shakkimestarien toimivan ennusteiden vastaisesti eli varsin intuitiivisesti, toisin kuin tuolloin kehitetyt, ihmisen pelaamista jäljittelevät tietokoneohjelmat.

Eksperttiyden olemusta on 1960 -luvun lopun ja 1970 -luvun alun jälkeen tarkasteltu monilla ammattialueilla. Kohteina ovat olleet shakinpelaajien lisäksi esimerkiksi fyysikot, röntgenlääkärit, tietokoneohjelmoijat (ks. Chi ym. 1988) ja yhteiskuntatieteilijät (Voss ym. 1983).

Eksperttiys on näissä tutkimuksissa yleensä määritelty ammattialaan kuuluvien ongelmanratkaisutehtävien tuloksellisen suorituksen perusteella. Opettajaeksperttiyden määrittely on, edellä mainituista muista aloista poiketen, osoittautunut vaikeammaksi ongelmaksi. Leinhardt on tutkimuksissaan käyttänyt eks. perttiyden kriteerinä opettajan pitkäaikaista menestystä työssään (Leinhardt $\varepsilon$ Greeno 1986). Tätä menestystä on mitattu koko luokan tuloksilla standardoiduissa koulusaavutus. kokeissa. Eksperttien ryhmään Leinhardt on sijoittanut opettajan, jonka luokka on sijoittu. nut parhaimman viidenneksen joukkoon tutkitun oppiaineen koulusaavutuskokeissa vä. hintään kolmen vuoden ajan viimeisten viiden vuoden aikana. Muita kriteerejä eksperttiydel. le ovat olleet esimerkiksi kollegojen ja oppilaiden arvioinnit sekä kokeneisuus.

Kennedy (1987) on tarkastellut muita eks. perttiyden määrittelyssä mahdollisia menetel. miä. Hänen mukaansa opettajaeksperttiys voidaan ymmärtää opetusteknisenä taitavuutena, kykynä soveltaa teorioita tai yleisiä periaatteita tai kykynä analyyttiseen ja ammatilliseen ajatteluun. Käytännössä näiden ominaisuuksien mittaaminen on kuitenkin vaikeaa ja siksi eks. perttiystutkimuksissa käytetyt määrittelykriteerit ovat muodostuneet toisenlaisiksi. 


\section{OPETTAJAEKSPERTTIYDEN OLEMUS JA KEHITYS TUTKIMUISTEN VALOSSA}

Opettajien eksperttiystutkimuksen aloittajana voidaan pitää Pittsburghin yliopistossa toimivaa Gaea Leinhardtia. Hän on tutkimuksissaan keskittynyt erityisesti matematiikan opettajien eksperttiyden kehityksen tutkimukseen. Ensimmäisessä eksperttiyttä käsitelleessä tutkimuksessaan hän tarkasteli eksperttien ja noviisien eroja sen suhteen, millaisen arvion he antoivat oppilaille annetun opetuksen ja ko. keen päällekkäisyydestä sekä oppilaiden suoritustasosta ko. kokeessa (Leinhardt 1983).

Myöhemmissä tutkimuksissaan Leinhardt on keskittynyt mm. matematiikan ekspertti- ja noviisiopettajien oppiainetietämyksen erojen selvittämiseen sekä oppituntirutiinien kehitty. neisyyden eroihin (esim. Leinhardt 1987). Leinhardtin tutkimukset ovat hyvä esimerkki lähestymistavasta, jonka avulla on haluttu selvittää tietämyksen olemusta ja sen kehittymistä. (Tietämyksellä, knowledge, tarkoitetaan tässä yhteydessä yksilön omaksuman informaation, esimerkiksi faktat, proseduurit, asen. teet, uskomukset, muodostamaa kokonaisuutta yksilön muistijärjestelmässä.) Tähän tutkimustavoitteeseen pyrittäessä on tavallisesti käytetty ns. ekspertti - noviisi -tutkimusasetelmaa, jossa em. ryhmiä verrataan toisiinsa.

Ekspertti-noviisi -paradigma, joksi tätä asetelmaa myös kutsutaan, ei kuitenkaan korvaa pitkittäistutkimusten antamaa tietoa yksittäisten koehenkilöiden kehityksen vaiheista. Tarvitaan myös pitkittäistutkimusta, jonka avulla voidaan kuvata tarkemmin kehityksen vaiheita. Ekspertti-noviisi -paradigman käyttö tutkimuksissa mahdollistaa hypoteesien muodostamisen tietämysrakenteiden ja niihin liittyvän informaationkäsittelyn muutoksista esimerkiksi $10-15$ vuoden ammattiuran aikana.

Eksperttiystutkimuksen yleisenä tavoitteena on Glaserin (1976) esittämän mallin mukaisesti selvittaaä tietämyksen lähtötaso ja välivaiheet, joiden kautta noviisit kehittyvät eksperteiksi. Eksperttiyden kehityksessä on kysymys ammatissa tapahtuvan oppimisen tuottamista muutoksista yksilön osaamiseen ja sen perus. tana olevaan tietämykseen.

Erityisen ansiokkaasti tähän näkökulmaan on paneutunut David Berliner Arizona State University'stä. Berliner on kehittänyt teorian opettajaeksperttiyden kehittymisen vaiheista käyttäen pohjana muilla ammattialueilla tehty. jä teorioita (vrt. Dreyfus $E$ Dreyfus 1986). Berlinerin (1988) teoria kuvaa opettajaeksperttiy. den kehitystä viisiportaisena prosessina. Seuraavassa kuvatut vaiheiden nimitykset ovat Berlinerin, sisällölliset kuvaukset perustuvat myös muuhun keräämääni lähteistöön.

\section{Vaihe 1: Noviisi.}

Noviisina voidaan pitää opettajankoulutuksen läpikäynyttä, mutta käytännön opetuskokemusta vain vähän tai ei lainkaan omaavaa opettajaa. Noviiseja ovat myös opettajankou. lutuksessa olevat opiskelijat, jotka toimivat opettajina. Noviiseilla on yleensä varsin erittelemättömiä mielikuvia omien oppilasvuosien aikana havainnoiduista opetuskäytänteistä ja niiden toimivuudesta. Nämä mielikuvat on vähitellen pystyttävä muuntamaan opetuksen erilaisiin tilanteisiin sopiviksi toimintaohjeiksi. Opetuksen vaiheet on opittava paitsi nimeämään myös toteuttamaan mahdollisimman sujuvasti käytännön tilanteissa.

Noviisien opetustoiminta on yleensä rationaalista, suhteellisen joustamatonta ja pyrkii noudattamaan mahdollisimman pitkälle niitä ohjeita ja sääntöjä, joita he ovat oppineet. Opetuksen rutiinit ovat muodostumisvaiheessa, eikä toiminta ole aina optimaalisen sujuvaa. Noviisin tyypillisenä piirteenä voi myös olla tarkkaavaisuuden käyttäminen pääasiassa oman toiminnan sujumisen seurantaan. Näin ollen oppilaissa tapahtuvat prosessit eivät saa noviiseilta yhtä suurta huomiota kuin ne saavat kokeneemmilta opettajilta. Kehittyäkseen on noviisien Berlinerin (1988) mukaan tärkeää saada kokemuksia todellisista opetustilanteista - ei vain verbaalista informaatiota niiden piirteistä.

\section{Vaihe 2: Kehittynyt aloittelija (advanced beginner)}

Tälle tasolle on tyypillistä, että ns. verbaalinen tietämys asioista alkaa yhdistyä omiin kokemuksiin. Samanlaisuudet eri opetustilanteiden välillä alkavat tiedostua ja opettaja kartuttaa episodimuistiaan tilannekohtaisella ja yksittäisiä oppilaita koskevalla 'case'-tietämyksellä. Strateginen tietämys alkaa myös kehittyä. Tämä näkyy esimerkiksi siinä, ettei opittuja toimintaohjeita noudateta mekanistisesti, vaan tilanteiden erityispiirteet pystytään paremmin ottamaan huomioon. 
Berliner (1988) antaa esimerkkejä tällä tasolla olevan opettajan tietämyksestä ja toiminnasta. Opettaja voi esimerkiksi huomata, ettei oppilaan kannustaminen aina tuota toivottua tulosta. Heikkotasoisimmat oppilaat saattavat tulkita kiitoksen osoitukseksi vaatimustason alhaisuudesta. Opettaja voi myös havaita, että kritiikki huonon suorituksen jälkeen voi olla motivoivaa hyvin menestyvälle oppilaalle.

Kehityksestä huolimatta 'kehittyneellä aloittelijalla' on yleensä vaikeuksia erottaa tärkeitä ja vähemmän tärkeitä opetustilanteiden piirteitä toisistaan. Vastuullisuuden kokemisessa opetuksesta on myös selviä eroja aloittelijoiden ja kokeneempien opettajien välillä. Aloittelijoiden kyky vastuun ottamiseen on Berlinerin (1988) mukaan puutteellinen siksi, että pyrkiessään kuvailemaan ja nimeämään erilaisia tilanteita ja noudattamaan oppimiaan sääntöjä ja periaatteita, he eivät kokonaisuutena tiedosta, mitä opetuksessa tapahtuu. Persoonallisen vastuun omaksuminen ja hyväksyminen tapahtuu siinä vaiheessa, kun opettaja pystyy itsenäiseen päätöksentekoon opetustilanteissa. Tämä tapahtuu Berlinerin (1988) mukaan yleensä seuraavan kehitysvaiheen aikana.

\section{Vaihe 3: Osaava suorittaja (competent performer)}

Berliner kuvaa kaksi ominaisuutta, jotka ovat tyypillisiä 'osaaville suorittajille'. Ensinnäkin he tekevät tietoisia valintoja sen suhteen, mitä aikovat tehdä. Toisin sanoen he laativat tavoitteita, asettavat niitä tärkeysjärjestykseen, tekevät suunnitelmia ja pohtivat niiden toteuttamisen vaihtoehtoja. Toinen ero edellä kuvattuihin ryhmiin verrattuna on kyky arvioida, mikä on tärkeää ja mikä ei. Suorittajan tasolla olevat opettajat tekevät harvoin virheitä asioiden opettamisen ajoituksessa tai opetettavien asioiden sisällöissä. Heillä on Berlinerin (1988) mukaan myös kyky tehdä itsenäisiä opetussuunnitelmallisia ja opetuksellisia ratkaisuja, esimerkiksi siinä, miten kauan tietyn oppilasryhmän kanssa viivytään opetettavassa aihepiirissä.

'Suorittajan' tason saavuttaneet opettajat kokevat yleensä vastuuta siitä, mitä opetuksessa tapahtuu. Tämä johtuu Berlinerin (1988) mukaan siitä, että he kontrolloivat opetustilannetta tiiviimmin kuin noviisit tai aloittelijat. He toteuttavat suunnitelmiaan ja tarttuvat vain niihin opetustilanteen seikkoihin, jotka heistä itsestään tuntuvat tärkeiltä. Emotionaaliset reaktiot onnistumisesta tai epäonnistumisesta saattavat olla suorittajilla voimakkaampia kuin edeltävillä tasoilla olevilla. 'Suorittajat' yleensä myös muistavat onnistumisiaan ja epäonnistumisiaan paremmin kuin edeltävillä tasoilla olevat. Suorittaja ei kuitenkaan ole ko. vin nopea tai joustava opetuskäyttäytymises sään ja tämä ominaisuus erottaa hänet seuraavien kehitystasojen opettajista.

\section{Vaihe 4: Taitava suorittaja (proficient performer)}

Tälle vaiheelle on tyypillistä, että intuitio ja osaaminen tulevat tyypillisiksi opettajan piirteiksi. Intuitiolla tarkoitetaan tällöin kykyä ha. vainnoida kokonaisvaltaisesti ympäristön piirteitä ja siinä esiintyviä invariansseja ja tuottaa näistä itselle intuitiivinen, erittelemätön, kokonaiskuva. Opettaja voi esimerkiksi intuitiivisesti tiedostaa, että tämän päiväinen matematiikan tunti epäonnistui samasta syystä kuin edellisen viikon äidinkielen tunti. Intuitio on kykyä tehdä korkean abstraktiotason luokituksia ja vertailuja ja ymmärtää niitä.

'Taitaville suorittajille' on tyypillistä pystyä tarkempiin ennusteisiin kuin edeltävien tasojen opettajat. Tämä johtuu siitä, että he pystyvät käyttämään tekemiään luokituksia ja 'teorioita' ja luokittelemaan koettuja tilanteita suhteessa näihin korkean tason intuitioihin tehokkaammin kuin edeltävillä kehitystasolla olevat opettajat. Kokeneet shakinpelaajat, lennonjohtajat ja röntgenlääkärit luottavat myös tähän kykyyn päätöksenteossaan. Taitava suorit. taja on intuitiivinen havainnoinnissaan ja asioiden tiedostamisessa, mutta edelleen kuitenkin analyyttinen ja tiedostava toimintaa koskevassa päätöksenteossa.

\section{Vaihe 5: Ekspertti}

Kun noviisia, kehittynyttä aloittelijaa ja osaavaa suorittajaa voidaan kuvata rationaaliseksi ja taitavaa suorittajaa intuitiiviseksi, eksperttiä voitaisiin paremminkin kuvata Berlinerin (1988) mukaan arationaaliseksi. Eksperteillä on intuitiivisuutta kokonaiskuvan hahmottamisessa eri tilanteista ja samalla ei-analyyttinen ja usein tiedostamaton käsitys siitä, millaisia toimenpiteitä tilanne vaatii. Heidän toimintansa on joustavaa ja tilanteeseen hyvin sopivaa. Ekspertit näyttävät tietävän, mitä pitää tehdä pystymättä välttämättä kuvailemaan ulkopuo- 
liselle toimintansa perusteita tai ajattelunsa kulkua. Berliner (1988) kuvaa esimerkkejä eksperttiyden ilmenemismuodoista eri am. mattialueilla kilpa-ajajasta opettajaan. Kilpaajajilta lainatut kommentit kuvaavat heidän tuntevan tulevansa osaksi ajokkiaan, ja eksperttiopettaja voi kuvata tunnin kuluneen niin sujuvasti, ettei hänen tarvinnut 'opettaa' lainkaan.

Ekspertit eivät tietoisesti valitse sitä, mitä he tekevät. He pystyvät monesti toimimaan ilman tietoista päätöksentekoa tilanteen vaatimusten mukaan. Tätä Berliner (1988) kuvaa arationaalisena toimintana, koska sitä on vaikea kuvata deduktiivisena tai analyyttisena käyttäytymisenä. Myöskään irrationaalisuus ei sovi toiminnan kuvaukseksi.

Ekspertit toimivat yleensä tuloksellisesti ja jos tilanre ei ole ongelmallinen, ekspertin ajattelu etenee 'kuin siivillä' intuition varassa. Tilanteen vaatiessa eksperttikin voi joutua käynnistämään tietoisen analyyttisen pohdintansa, mutta yleensä ekspertit eivät tietoisesti mieti toimintansa etenemistä tai sen perusteita (Berliner 1988, 43).

\section{EKSPERTTIYDEN KEHITTY- MISEN PERUSPIIRTEET?}

Eksperttiyttä koskevasta tähänastisesta tutkimuksesta voitaisiin poimia pitkä luettelo asioita tai ominaisuuksia, jotka näyttävät erottavan ekspertit ja noviisit. Erojen löytäminen on kuitenkin vain alku tutkimukselle. Erot on pystyttävä myös tulkitsemaan teoreettisesti mielekkäällä ja tutkimusta ohjaavalla tavalla. Seuraavassa tarkastellaan saatuja tuloksia tästä näkökulmasta.

Väite 1: Eksperttiys kehittyy vain kapealle tietämysalueelle ja sen perustana oleva tietämys on hyvin kontekstisidonnaista.

Eksperttiys voi syntyä vain pitkällisen kokemuksen tuloksena. Shakkimestareiden on arvioitu viettåneen pelin äärellä 10 000-20 000 tuntia, eksperttiröntgenlääkäreiden tulkinneen lääkärivuosiensa aikana noin 100000 röntgenkuvaa ja eksperttiopettajien toimineen opettajina luokassa ainakin 10000 tuntia ja sitä ennen olleen itse oppilaina ainakin 15 000 tuntia (Berliner 1990). Näin ollen ei näytä mahdolliselta, että yksilö voisi hankkia perusteellista tietämystä kovin monilta osaami- sen alueilta tai että eksperttiys voisi olla laajaalaista, monelle osaamisen alueelle kelpaavaa.

Vaikka eksperteillä onkin runsaasti tietä. mystä, se on hyvin tilannespesifiä. Berliner (1990) kuvaa tämän tilannespesifin tietämyksen luonnetta kertoessaan tutkimuksesta, jossa joukkoa ekspertti- ja noviisiopettajia sekä aloittelijoita pyydettiin opettamaan 30 minuutin jakso lukiotasoisille oppilaille. Koehenkilöille annettiin puoli tuntia aikaa suunnitella jak. son sisältö, minkä jälkeen he toteuttivat oppitunnin. Tunti videoitiin ja jälkeenpäin koehenkilöitä pyydettiin kertomaan ajatuksistaan katsellessaan omaa tuntiaan kuvanauhalta. Tutkijoiden yllätykseksi eksperttiopettajat suhtautuivat tilanteeseen hyvin emotionaalisesti. Kukaan eksperteistä ei pitänyt annetusta tehtävästä, vaikka heillä näyttikin olevan taitoja hoitaa tilanne tehokkaammin kuin aloittelijoilla tai noviiseilla. Yksi eksperttikoehenkilöistä keskeytti osallistumisensa, yksi alkoi itkeä omaa tuntia katsellessaan ja kaikki muut olivat vihaisia tutkijoille. Syy vihamielisyyteen oli siinä, etteivät ekspertit kokeneet onnistuvansa tilanteessa, jossa heidät oli siirretty pois omasta luokastaan ja tilanteista, jotka olivat heille tuttuja. Kun suunnitteluaikaa oli annettu puoli tuntia, jotkut eksperteistä olisivat halunneet kolme tuntia tai jopa viikon ko. tunnin valmistamiseen. Lisäksi he valittivat sitä, etteivät tunteneet luokan oppilaita. Berlinerin (1990) tulkinta oli, että eksperteillä ei tutkimustilantees. sa ollut sellaista toimintakontekstia, jossa he olisivat kokeneet pystyvänsä toimimaan tehokkaasti.

Tätä opettajatietämyksen kontekstuaalisuutta ja tilannesidonnaisuutta on myös Leinhardt (1988) korostanut. Opettajan kokemuk. set liittyvät konkreetteihin luokkatilanteisiin ja niiden tuloksena karttuu tietämystä, joka on suoraan sovellettavissa vain samanlaiseen tilanteeseen.

Tässä yhteydessä voidaan tietysti kysyä, voiko opettajasta koskaan tullakaan eksperttiä samassa mielessä kuin esimerkiksi shakinpelaajista tai röntgenlääkäreistä, koska hyvältä opettajalta vaaditaan myös laaja-alaisuutta. Laaja-alaisuuden vaatimuksella saatetaan tällöin viitata esimerkiksi niihin moniin oppiaineisiin, joihin opettajan tulee olla perehtynyt.

Oma kantani on, että opettaja voi kehittyä ekspertiksi siinä kuin muidenkin ammattialojen asiantuntijat. Laaja-alaisuusvaatimuskin on ehkä vain myytti, sillä opettajan ydinosaami- 
nen ei liity niinkään oppiaineiden sisältöihin, vaan niiden opettamisen problematiikkaan luokkaopetuksessa. Kouluopettajan ei tarvitse olla asiantuntija niissä aineissa, joita hän opettaa. Riittää, että hän tuntee ne aihepiirit hyvin, jotka kuuluvat koulun opetussuunnitelmiin.

Opettajan keskeisintä osaamisen aluetta voi tästä näkökulmasta pitää jopa varsin kapeana. Opettajaekspertillä on oltava runsaasti kokemuksen ja koulutuksen kautta hankittua tietämystä, joka on integroitunut jäsentyneiksi 'teorioiksi' ja niihin liittyviksi joustaviksi toiminta. valmiuksiksi erilaisissa luokkatilanteissa.

Toinen kysymys liittyy opettajaeksperttiyden kehittymismahdollisuuksiin. Voidaanko esimerkiksi olettaa, että normaali koulutyö kehittää opettajan tietämyksen eksperttiystasolle ? Tässä suhteessa opettajan ammatti on mielestäni edellä kuvatuista muista eksperttiystutkimusten kohteista poikkeava. Kun shakinpelaaja tai röntgenlääkäri yleensä aina scıa palau. tetta tulkintojensa oikeellisuudesta tai tekemiensä ratkaisujen tuloksista, ei opettajan am. matista voi sanoa samaa. Palautetta saadaan oppilaiden saavuttamista tuloksista, mutta monesti tämä palaute on ristiriitaista ja vaike. asti tulkittavaa. Opettaja voi löytää lähes mille tahansa toimintatavalleen sekä tukea että todeta epäonnistuneensa ottamalla palautteen tilanteen eri puolista tai esimerkiksi eri oppilaiden saavuttamista tuloksista.

Opettajana toimiminen ei mielestäni ole riittävä edellytys eksperttiyden kehittymiseen. Ammatin ja siinä annettavan koulutuksen osaksi olisikin liitettävä toimintamuotoja, jotka paremmin ylläpitäisivät ja kehittäisivät opettamiseen liittyvää pohdintaa ja edistäisivät niitä prosesseja, joiden tulosta eksperttiys aina on.

Vaaite 2: Eksperteillä on automaattisia reagointitapoja usein toistuvien opetuksen tilanteiden käsittelyyn

Yksi asiantuntijuutta koskevan tutkimuksen ensimmäisistä alueista liittyi automaattisten toimintojen kehittymiseen. Tämä oli suoraa jatkoa ihmisen yleistä informaationkäsittelyä koskeviin tutkimuksiin. Automaattisuuden kehittymisen tutkimustahan on tehty jo kauan esimerkiksi motoristen taitojen alueella.

Eksperttiystutkimuksissa automaattisuuden kehitystä on seurattu erityisesti ns. kognitiivisissa taidoissa. Esimerkiksi Glaser (1987) toteaa hyville lukijoille tyypillisen nopean ja au- tomaattisen tekstin ymmärtämisen vapauttavan heidän työmuistikapasiteettiaan tilanteen muiden piirteiden käsittelyyn.

Opettamisessa toimintojen automatisoituminen mahdollistaa tarkkaavaisuuden suuntaamisen muualle ja antaa näin mahdollisuuden opetustilanteen kokonaisuuden parempaan hallintaan. Yksi esimerkki kokeneiden opettajien taitojen automatisoitumisesta on poimittavissa Leinhardtin ja Greenon (1986) tutkimuksesta, jossa he vertailivat oppitunnin aloitusta eksperttien ja noviisien ala-asteen matematiikan tunneilla. Ekspertiksi arvioitu opettaja käytti ensinnäkin noin kolmasosan vähemmän aikaa tunnin aloitukseen kuin noviisi. Toiseksi ekspertti pystyi tilanteen aikana havainnoimaan oppilaiden aktiviteettia, selvittämään, ketkä olivat tehneet kotiläksynsä ja arvioimaan, ketkä tarvitsisivat apua myöhemmin tunnin aikana. Kolmanneksi eksperttien tunneille oli tyypillistä sujuvuus ja tunnin hallinta, minkä perustana olivat opettajien automaattiset rutiinit, jotka sekä opettajat että heidän oppilaansa olivat oppineet.

Noviisien tunteja voitiin ko. tutkimuksessa kuvata lähes päinvastaisina. Noviisit eivät täysin hallinneet tuntien kulkua. Heillä oli vaikeuksia saada oppilaat tarkkaavaisiksi ja selvittää, ketkä olivat tehneet läksynsä. Noviisien kysymykset kotiläksyistä eivät olleet yhtä selkeitä kuin eksperttien ja johtivat siten noviiseja arvioimaan väärin läksyjen vaikeustason. Heille ei myöskään samassa määrin selvinnyt, ketkä oppilaista tarvitsisivat lisäohjausta. Keskeinen erottava tekijä ekspertin ja noviisin välillä oli lisäksi tunnin hallinnan rutiinien puuttuminen tai niiden kehittymättömyys noviiseilla. Tämä aiheutti epävarmuutta sekä noviisiopettajien että oppilaiden toimintaan. (Leinhardt $\mathcal{E}$ Greeno 1986.)

Käsitelty esimerkki on vain yksi osoitus opettajan rutiinien tärkeydestä oppituntitilan. teissa. Opettajan toimintaympäristö on kokonaisuudessaan niin monimutkainen, ettei sitä voi hallita sujuvasti ilman automaattisia tai lä. hes automaattisia rutiineja. Automaattisia rutiineja voidaan tietenkin pitää ei-toivottuina, jos ne ymmärretään vain mekaanisesti suoritettavina toimintoina, jotka opettaja toteuttaa huomioimatta kunkin tilanteen erityispiirteitä. Eksperttien rutiinit ovat kuitenkin joustavia. Toisin sanoen kokeneet opettajat näyttävät varioivan toimintojaan ja mukauttavan rutiinit noviiseja tehokkaammin kontekstin vaatimusten mukaisiksi (ks. Berliner 1988). 
Väite 3: Ekspertit ovat noviiseja sensitiivisempiä ongelmien ja ongelmanratkaisutilanteiden erityispiirteille

Ongelmanratkaisua tutkittaessa on eksperttien havaittu pystyvän ottamaan huomioon noviiseja monipuolisemmin kontekstin piirteet ja ongelmiin sisältyvät rajoitukset (ks. Chi ym 1982; Glaser 1987).

Opettajaeksperttiyden alueella samaa aihepiiriä ovat tutkineet mm. Housner ja Griffey (1985), jotka vertailivat kokeneita ja aloittelevia liikunnanopettajia. Tutkimuksen koehenkilöinä oleville opettajille annettiin tehtäväksi lyhyehkön opetusjakson suunnittelu ja toteutus. Suunnittelúvaiheessa molemmat ryhmät tekivät yhtä paljon kysymyksiä esimerkiksi oppilasmäärästä, oppilaiden iästä ja sukupuolesta. Eksperttien ryhmässä tehtiin kuitenkin noviiseja enemmän kysymyksiä oppilaiden kyvyistä, kokemuksesta ja taustasta sekä käytettävissä olevan tilan piirteistä ja välineistä. Viisi kahdeksasta kokeneesta opettajasta halusi jopa nähdä tilan ennen suunnittelun alkua. Kukaan noviiseista ei pyytänyt tätä.

Myöhemmin opetusta toteutettaessa kokeneet opettajat mukauttivat opetustaan no. viiseja enemmän tilanteen mukaiseksi poiketen siten ennakkosuunnitelmistaan. Pääperusteina muutoksiin olivat oppilaitten suoritustasosta, osallistumisesta sekä oppilaitten mielialoista tehdyt päätelmät. Noviiseilla pääperuste muutoksiin oli oppilaitten esittä. mät arviot opetuksen kohteena olevista toiminnoista. Toisin sanoen noviisit poikkesivat suunnitelmista, jos oppilaat sitä pyysivät. Kokeneet opettajat sitä vastoin muuttivat suun. nitelmia oppilaista tekemiensä päätelmien ja tulkintojen perusteella (ks. Berliner 1990).

Omissa tutkimuksissani kokeneista ja aloittelevista opettajista havaittiin eroja, jotka näyttäisivät viittaavan edellä kuvatun kaltaisiin tilanneherkkyyden eroihin. Ensimmäisessä tutkimuksessa vertailtiin matematiikan (Ropo1990a) ja toisessa englannin kokeneiden ja aloittelevien opettajien eroja oppituntikyselyssä (Ropo 1990b). Tutkimusaineisto koottiin observoimalla. Aloittelevien opettajien ryhmä muodostui opettajakokelaista ja kokeneiden ryhmä normaalikoulun ohjaavista opettajista.

Molemmissa tutkimuksissa todettiin kokeneiden ja aloittelijoiden välillä eroja siinä, millaisin keinoin he pyrkivät korjaamaan oppi- laiden vääriä vastauksia. Matematiikan kokeneet opettajat käyttivät noviiseja enemmän alkuperäisen kysymyksen osittamista tai vas. tausvaihtoehtojen esittämistä keinona oikean vastauksen saamiseen oppilailta. Englannin kokeneet opettajat puolestaan käyttivät esimerkkejä edesauttaakseen oppilaan ajattelua vastaustilanteessa. Noviisit eivät esittäneet esimerkkejä oppilaiden väärien vastaus. ten korjauskeinona kertaakaan kuunneltujen englannin tuntien aikana. Alkuperäisen kysymyksen osittaminen useaksi pienemmäksi kysymykseksi oli puolestaan tyypillisempää englannin noviiseille kuin kokeneille, joilla kysymysten osittamista esiintyi vain kaksi kertaa kuunneltujen 13 tunnin aikana. Noviisien 11 tunnilla kysymyksen osittamista tapahtui 17 kertaa. (emt.)

Molemmat edellä kuvatut tutkimukset osoittavat noviisien ja kokeneiden reagoivan toisistaan poikkeavilla tavoilla oppilaiden vääriin vastauksiin. Osa eroista selittyy ehkä sillä, että noviisit joutuvat korjaamaan teke. miään 'virheitä' esimerkiksi kysymysten muotoilussa. Kokeneilla opettajilla reaktioi. den erot oppilaiden vääriin vastauksiin eivät ehkä ole oman virheen korjaamista, vaan perustunevat erilaisiin tulkintoihin oppilaiden virheiden syistä. Opettaja saattaa esimerkiksi tulkita väärän vastauksen johtuneen oppilaan tarkkaamattomuudesta, kysymyksen aiheuttamista vääristä assosiaatioista tai siitä, ettei oppilas muista jotakin asiaan liittyvää aikaisempaa tietoa. Näin tapa 'korjata' oppilai. den vääriä vastauksia kuvastaa opettajan pe. dagogista osaamista (kysymystekniikka), tietämystä oppilaiden oppimisesta ja erilaisten virheiden syistä (mitä tietoa oppilaalta puuttuu, jos hän vastaa väärin tämäntyyppiseen kysymykseen) sekä tilannesensitiivisyyttä (miksi tämä oppilas vastasi nyt väärin).

Tulosten perusteella voidaan kokeneiden opettajien katsoa omaavan noviiiseja syvällisempää tietämystä ainakin edellä mainituis. sa asioissa.

Väite 4: Eksperttiopettajat pystyvät nopeaan ja tarkkaan tilanteiden havainnoin. tiin. Noviisit eivät samassa määrin pysty tulkitsemaan kokemuksiaan opettamisen kannalta mielekkäåsti.

Eräs monissa eksperttiysanalyyseissa havaittu seikka on ekspertin kyky tunnistaa ja tulkita nopeasti ja automaattisti tilanteita. Tämä ominaisuus on havaittu ennen opettajia esimerkiksi shakkimestareilla ja kokeneilla röntgenlääkäreillä. 
Tilanteiden nopea tunnistus ja tulkinta perustuu muistiin tallennetun tietämyksen määrään ja laatuun. Yksilön muistissa on niin runsaasti esimerkiksi erilaisia tilanneskeemoja, että koettuun tilanteeseen sopiva tulkintaskeema löytyy. Nopean tulkinnan edellytys on myös se, että tietämysrakenteet (esimerkiksi skeemat) ovat organisoituneet tavalla, joka mahdollistaa nopean tunnistuksen ilman pitkää prosessointia. Nopea tilanteiden tunnistus on yksilön toiminnan kannalta hyödyllistä, koska se vähentää eri tilanteissa vaadittavan prosessoinnin tarvetta. Näin se vapauttaa prosessointikapasiteettia tilanteen vaatimiin toimenpiteisiin.

Berlinerin (1990) tutkimuksessa todettiin eksperttiopettajien tunnistavan lyhyen diaväläyksen perusteella noviiseja paremmin, mistä tunnista ja tunnin vaiheesta kuvissa oli kysymys. Tilanteiden tunnistuksen erot näkyivät selvästi myös Berlinerin toisessa tutkimuksessa, jossa koehenkilöitä pyydettiin samanaikaisesti seuraamaan kolmella videomonitorilla esitettyjä nauhoituksia samasta opetustilanteesta. Noviiseille jo kolmen monitorin samanaikainen seuranta oli vaikeaa. Lisäksi heidän kertomuksissaan nähdyistä tapahtumista ja niiden merkityksistä ilmeni ristiriitaisuuksia. Ekspertit pystyivät samassa koetilanteessa suuntaamaan paremmin havainnointiaan monitorista toiseen ja tekemään oikeita tulkintoja esimerkiksi kuvatun tilanteen sisällöstä, oppitunnin vaiheesta tai oppilaiden aktiivisuudesta (Berliner 1990).

Väite 5: Eksperttien ongelman hahmotus on hitaampaa kuin noviisien, mutta johtaa parempaan ongelman represen. taatioon.

Viime vuosikymmenen alkupuoliskolla Pittsburghin yliopistossa toimivat tutkimusryhmät tarkastelivat ongelmanratkaisuprosessin eroja eri alojen eksperteillä ja noviiseilla (ks. Chi ym. 1981). Tulokset esimerkiksi fyysikkojen ja yhteiskuntatieteilijöiden ongelmanratkaisuprosessista osoittivat, että ekspertit käyttävät enemmän aikaa ongelman hahmotusvaiheeseen kuin noviisit (Chi ym. 1981; Voss ym. 1983).

Hanninen (1983) on havainnut samansuuntaisen eron ekspertti- ja noviisiopettajien ongelmanratkaisussa. Hannisen tutkimuksessa koehenkilöille annettiin ratkaistavaksi lahjak. kaiden oppilaiden opettamiseen liittyvä ongelma. Hanninen mittasi aikaa ongelman antami- sesta ratkaisun aloittamiseen. Noviisit käyttivät keskimäärin 2,6 minuuttia ja lahjakkaiden opettamisessa kokeneet ekspertit 9,8 minuuttia, ennen kuin alkoivat kirjoittaa ratkaisua. Normaaliluokissa opettaneiden kokeneiden opettajien keskimääräinen miettimisaika ko. tehtävässä oli kolme minuuttia. (Berliner 1990.)

Tuloksista voi päätellä, että yksilön tietämyksen määrä korreloi ongelman represen. taation muodostamiseen kuluvaan aikaan. Mitä enemmän yksilö tietää, sitä paremmin hän pystyy ottamaan huomioon tilanteen monimutkaisuuden ja representoimaan sen ongelman hahmotuksessaan.

Tällainen prosessointi vaatii perusteellista tietämyksen läpikäyntiä ja vaihtoehtojen pohdintaa ja vaatii siksi pitemmän ajan. Pitempi työskentely ongelman hahmottamiseksi näyttää sitten johtavan ongelman tehokkaampaan ratkaisuun. Fyysikoilla ja yhteiskuntatieteilijöillä tämä näkyi teoriatason huomioon ottamisena ongelmanratkaisussa (Chi ym. 1981; Voss ym. 1983).

Eksperttiopettajilla luokkatilanteisiin liittyvät ratkaisut ovat sisältäneet pitempiä ja perusteellisempia tilannetekijöiden analyyseja (Nel. son 1988) tai tehtyjen ratkaisujen runsaampia ja loogisempia perusteluja (Peterson $\mathcal{E}$ Comeaux 1987). Sama asia saattaa ilmetä myös ongelmaan annetun vastauksen pituudessa tai sen sisällön monipuolisuudessa, kuten oma tutkimukseni kokeneiden ja aloittelevien opettajien oppilastietämyksestä osoitti (Ropo 1990b).

Kokeneet opettajat käyttivät 35 prosenttia enemmän sanoja kuvatessaan oppilaita kuin aloittelijat. Vain vähäistä eroa oli siinä, miten monta erilaista ominaisuutta ko. opettajaryhmät löysivät oppilaistaan (ekspertit kuvasivat noin 10 prosenttia useampia ominaisuuksia).

Sitä vastoin ryhmät erosivat siinä, miten monipuolisesti oppilaita kuvattiin (Ropo 1990b). Kertomusten sisällöllinen analyysi osoitti, että ekspertit liittävät oppilaskuvauksensa laajempaan 'teoriakehykseen'. Heillä esiintyi selvästi enemmän mainintoja oppilaiden ominaisuuksien alkuperästä (esimerkiksi kodin vaikutuksesta) tai syistä sekä niiden merkityksestä oppilaan tulevaisuuteen. Kuvatessaan oppilaiden koulumenestystä eksperttien kuvaus oli konkreettisempaa ja spesifim. pää. He käyttivät mm. enemmän esimerkkejä 
kuvatessaan oppimisvaikeuksien laatua. Oppilaiden persoonallisuudesta kertoessaan ekspertit kuvasivat oppilaan koulukäyttäytymistä sekä oppilaan persoonallisuuden kehitystä tai persoonallisuuden piirteiden taustaa noviiseja useammin.

Tulokset viittaavat siihen, että eksperttien kertomukset oppilaistaan perustuvat pitem. mälle kehittyneisiin oppilastietämyksen skee. moihin. Niiden avulla he pystyvät hankkimaan ja tallentamaan perusteellisempaa ja monipuolisempaa kulloistakin oppilasjoukkoaan koskevaa informaatiota. Kun ekspertit ja noviisit eivåt eronneet sen suhteen, miten kauan he olivat tunteneet oppilaansa, on kyseinen oletus perusteltavissa.

Myös Calderhead (1983) on viitannut kokeneiden ja aloittelijoiden oppilastietämyksessä oleviin eroihin ja todennut kokeneiden omaa. van enemmän tietämystä oppilaista. Calderhe. adin (1983) mukaan ne skeemat, joita kokeneilla opettajilla on oppilaista, saattavat poiketa merkittävästi aloittelevien opettajien tietämysrakenteista. Kokeneilla opettajilla oli runsaasti yleistä tietämystä oppilaista. He näyttivăt jopa 'tuntevan' oppilaansa, ennen kuin olivat edes tavanneet heitä. Tietämys liittyi oppilaiden kotitaustan tuntemukseen, oppilaiden tietämyksen ja taitojen tason tuntemukseen ja arvioon siitä, kuinka moni tulisi tarvitsemaan myöhemmin yksilöllistä ohjausta. Lisäksi ko. keneet pystyivät paremmin arvioimaan häiriökäyttäytymisen laatua ja määrää, oppilaiden kokemustaustaa ennen koulua ja koulun ulko. puolisia harrastuksia.

Väite 6: Eksperttiopettajien tietämys sisältää useampia abstraktiotasoja ja on organisoitunut hierarkkisemmin kuin noviisien.

Eksperttien ja noviisien tietämyksen jäsentymisessä on havaittu eroja, joiden perusteella voidaan olettaa eksperttien tietämyksen muo. dostuvan useammista, hierarkkisesti toisiinsa yhteydessä olevista tasoista. Tämä ilmenee esimerkiksi ongelmanratkaisutilanteista tehdyissä kuvauksissa usean eritasoisen elementin mukanaolona ongelmasta muodostetussa representaatiossa. Esimerkiksi Chin ym. (1981) tutkimuksessa eksperttifyysikoiden vinoa tasoa käsittelevän ongelman representaatio sisälsi fysiikan peruslainalaisuudet, joita noviisit (aloittelevat fysiikan opiskelijat) eivät tuoneet lainkaan esiin ongelmaa kuvatessaan. Voss ym. (1983) päätyivät vastaavanlaisiin hie. rarkkisuuden eroihin analysoidessaan yhteiskuntatieteilijöiden ongelman hahmotusta ja ratkaisuprosessointia.

Omissa tutkimuksissani tietämyksen laadullisia eroja on tarkasteltu matematiikan opetta. jien opetustavoitteiden yhteydessä (Ropo 1987). Eksperttien tietämys opetuksen tavoitteista sisälsi hierarkkisuutta, joka ilmeni esimerkiksi spontaanina tavoitteiden jäsentelynä eri koulu- ja luokka-asteille sekä tavoitteiden yleisyyden mukaan (oppiaineen yleistavoite vs. spesifit osatavoitteet). Noviiseilla yleistavoitteiden taso oli jäsentymätön ja sisälsi asioita, jotka haastattelutilanteessa tuotettiin 'pakon edessä'. Toiseksi hierarkkisuus ilmeni tavoitteiden ajallisuuden suhteen. Kokeneet opettajat jäsensivät tavoitteet esimerkiksi pitkän ja ly. hyen aikavälin tavoitteiksi. Kokeneet opettajat kuvasivat tavoitteitaan noviiseja enemmän ottaen erilaisia esimerkkejä konkreeteista koke. muksistaan.

(Tarkasti ottaen on tehtävä ero siinä, ajatellaanko hierarkiatasojen olevan tietämysraken. teiden vai yksilön siitä tuottaman kuvauksen ominaisuus. Tässä oletuksena on kuitenkin, että hierarkkisuus kehittyy tietämyksen ominaisuudeksi.)

Konkreettisten esimerkkien käyttö oppilaiden oppimisesta tukee sitä oletusta, että koke. muksella on keskeinen merkitys abstraktin ja organisoituneen tietämyksen muodostumises. sa. Pelkkä kokemus ei kuitenkaan sinällään riitä, vaan kokemukset on tulkittava ja näille on löydettävä paikka muistin organisaatiossa. Tällainen organisoituminen näyttää vaativan vuosikausien työstämistä. Hierarkkioihin jäsentynyt tietämys kehittyy esimerkiksi tekemällä induktiivisen päättelyn periaatteilla joh. topäätöksiä konkreeteista kokemuksista.

Våite 7: Eksperttiopettajien pedagoginen suhde oppilaisiinsa poikkeaa noviisien suhteesta oppilaisiin

Edellä kuvattu luokanopettajia käsittelevä tutkimus sisälsi myös aineistoa, jonka perusteella voidaan olettaa eksperttien ja noviisien välillä olevan eroja siinä, millaisen pedagogisen suhteen he luovat oppilaisiinsa (Ropo 1990b). Eksperttien kertomuksista voitiin päätellä heidän näkemystensä oppilaista poik keavan noviiseista. Ensinnäkin, oppilaiden harrastuksia kuvatessaan kaksi kokenutta opettajaa suhteutti kuvaukset omiin harrastuk. siinsa. Toisin sanoen he kertoivat, harrastavat. ko ko. oppilaat samoja asioita (toinen opettaja 
harrasti urheilua, toinen musiikkia) kuin he itse.

Toinen viite oppilas-opettaja -suhteen erilaisuudesta tuli erään kokeneen opettajan kertomuksesta, jossa hän kertoi omista tunteistaan oppilaita kohtaan. Yksi kohteeksi valituista oppilaista oli hänen 'suosikkioppilaansa', josta hän piti kaikkein eniten, vaikkei halunnutkaan ilmaista sitä oppilaille. Toinen kohteeksi valittu oppilas oli ongelmallinen, koska opettaja ei mielestään saanut kontaktia tähän oppilaaseen. Ratkaistakseen kontaktiongelman hän suoritti säännöllistä oppilaan tarkkailua erilaisissa tunti- ja välituntitilanteissa. Kolmannesta joukkoon tulleesta oppilaasta opettaja kertomuksensa mukaan piti kaikkein vähiten. Tä. hän hän löysi myös selkeästi ilmaistavia syitä. Yksikään haastatelluista noviiseista ei kuvannut tällä spesifisyystasolla suhdetta oppilaisiin (Ropo 1990b).

Kuvatut seikat kokeneiden opettajien kerto. muksista tukevat sitä oletusta, että opettajan pedagogiikkaan liittyvien tietämysrakenteiden voi olettaa ohjaavan opettajan kaikkea informaationkäsittelyä havainnoinnista niiden tulkintaan. On perusteltua olettaa näiden tietä. mysrakenteiden olevan eksperttiopettajilla spesifioituneempia kuin noviiseilla. Edellä kuvatussa aineistossa kokeneisuus näyttää johta. van 'syvällisempään' suuntautumiseen oppilaita koskevassa havainnoinnissa ja näiden ha. vaintojen tulkinnassa.

Väite 9: Eksperttiopettajilla on erilainen käsitys opetuksen tavoitteista: ekspertit ymmärtävät kouluopetuksen oppilaiden taitojen kehittämisenä; noviisit orientoituvat oppilaiden ulkoisen käyttäytymisen mukaan

Tämä väite perustuu luokanopettajatutkimuksen tuloksiin (Ropo 1990b). Osana aineiston keräystä koehenkilöinä olleille opettajille annettiin luokan oppilaiden nimikortit ja heitä pyydettiin lajittelemaan oppilaat niin moneen luokkaan ja niin monella eri tavalla kuin mahdollista. Tässä luokittelutehtävässä noviisit näyttivät perustavan luokittelunsa oppilaan ulkoiseen käyttäytymiseen (aktiivisuus tunnilla, häiriökäyttäytyminen, välituntitoiminta yms.) tai ulkoisten ominaisuuksien mukaan (sukupuoli). Sen sijaan ekspertit jaottelivat oppilaita ryhmiin pääasiassa koulutyöskentelyssä osoitettujen taitojen mukaan (kirjoitustaito, matematiikan taidot). Myös tämän tuloksen voidaan katsoa osoittavan kokeneiden opettajien omaavan tietämysrakenteita, jotka johtavat noviiseista poikkeavien oppimis- ja opetustavoitekäsitysten muodostamiseen.

(Tietämysrakenteilla ymmärretään tässä yhteydessä niitä muistiin tallennettuja faktojen ja proseduurien verkostoja, jonka perusteella yksilö muodostaa erilaisia käsityksiään. Yksilön käsityksiä voidaan siten pitää informaationkäsittelytermein ilmaistuna työmuistiin muodostettuina mentaalimalleina tarkastelun kohtee. na olevasta asiasta.)

\section{YHTEENVETO}

Mitä edellä esitetyistä kuvauksista opettajaeksperttiyden kehittymisestä ja sen ilmenemismuodoista kokeneiden ja aloittelevien opettajien välisinä eroina voidaan sitten päätellä? Tarkastelen kysymystä ensin yleisellä tasolla ja sitten tulosten soveltamismahdollisuuksien näkökulmasta.

Eksperttiyden kehityksen tutkimuksen voidaan sanoa avanneen kokonaan uuden näkökulman oppimisen ja kehityksen tutkimukseen. Eksperttiystutkimuksen yleistä merkitystä voidaan kuvata seuraavasti:

a) Eksperttiystutkimukset ovat luoneet varsin kasvatusoptimistisen kuvan tietämyksen kehityksestä ja sen kehitysmahdollisuuksista.

Ensinnäkin tulokset osoittavat ihmisen tiedollisen kehityksen jatkuvuuden ja korostavat näin positiivista näkökulmaa yksilön kehitysmahdollisuuksiin. Kehitysmahdollisuuksien olemassaolon lisäksi kehityksen vaiheista on pystytty muodostamaan hypoteeseja. Toiseksi eksperttiyden kehitys ei näytä olevan liittyvän sellaisiin staattisiksi ominaisuuksiin kuin esimerkiksi älykkyys, vaan näyttää kehittyvän kapea-alaisena sille tietämyksen alueelle, jolla yksilö työskentelee riittävän pitkään. Tällainen kehitys on hidasta; kysymys on aina vuosikausia kestävästä prosessista, jossa ympäristön suunnalta tulevilla kehityshaasteilla on tärkeä merkitys.

b) Eksperttiystutkimus on tuottanut runsaasti uutta tietoa ihmisen tietämyksen luonteesta.

Eksperttiyden perustana oleva tietämys on moniulotteista ja laaja-alaista. Opettajilla se näyttää olevan samalla kertaa abstraktia ja teoreettista että konkretisoitavissa yksittäisiin kokemuksiin ja muistikuviin. Ekspertit näyttävät pystyvän perustelemaan abstraktit ja teoreettiset väittämänsä tilanne- ja tapaustiedolla. Tätä situationaalisen tietämyksen näkökulmaa on alettu tutkia vasta viime vuosina (esi- 
merkiksi Leinhardt, 1988). Teoreettisen tietämyksen voidaan olettaa pohjautuvan tilannetietämyksen reflektointiin, jossa yksilö 'synnyttää' teoreettisesti korkeatasoiset tietämysrakenteensa osat pohtimalla konkreettisten tilannekokemuksiensa merkitystä.

c) Eksperttiystutkimus on tuonut viitekehyksen, jonka perusteella voidaan tarkastella, millaiselle tietämyksen tasolle koulutus yksilön kohottaa ja millaista tietämyksen tasoa koulutuksen läpikäyneeltä voidaan ylipäänsä vaatia.

Eksperttiysviitekehyksen mukaan peruskoulutus tuottaa noviiseja, jotka ovat ammatillisen kehityksensä alussa. Tätä näkökulmaa voidaan käyttää opettajankoulutuksen ja ammatillisen jatko- ja täydennyskoulutuksen kehittämisessä. Peruskoulutuksen saaneiden opettajien nykyisen 'heitteillejätön' sijaan olisi suunniteltava riittävän tehokas koulun sisäinen järjestelmä noviisiopettajien perehdyttämiseen ja konsultointiin jatkuvan kehitysprosessin turvaamiseksi.

d) Neljänneksi voidaan todeta tietämysrakenteiden (skeemojen, sisäisten mallien tms.) tasolla tapahtuvan tutkimuksen tärkeys käsityksellemme oppimisesta ja kehittymisestä. Oppimista ei pidä pelkistää vain lyhyen aikavälin muutoksiksi, vaan on mielekästä ja hedelmällistä tutkia sitä pitkän aikavälin muutosproses. sina.

Mitä opettajaeksperttiystutkimukset ovat sitten paljastaneet opettajien ammattitaidon kehityksestä ?

Tähän kysymykseen vastaamisen voisi aloittaa yleisellä toteamuksella, että kokeneet opetta. jat ovat ammattitaitoisempia kuin aloittelijat. Miksi siis tutkia eroja?

Eksperttiystutkimuksen motiivina ei pohjimmiltaan ole todeta olemassaolevia eroja, vaan selvittää erojen luonnetta ja laatua. Tämä on tärkeää, jotta ylipäänsä tiedettäisiin millaisista prosesseista ammatillisessa kehityksessä on kysymys.

Tähänastiset tulokset ekspertti- ja noviisiopettajista ovat osoittaneet erojen olemassaolon ryhmien välillä. Erot näkyvät opettajien toiminnassa eri asteisesti ja niiden on katsottu tutkimusviitekehyksen mukaisesti kuvastavan tietämysrakenteiden kehittyneisyyden eroja. Toisaalta tutkimuksissa on havaittu hyvin selviä eroja, toisaalta joissakin tutkimuksissa löydetyt erot ovat varsin pieniä. Pienistä eroista voidaan tehdä se tulkinta, että joko opettajien ei työssään tarvitse kehittää näitä alueita tai sitten tutkitut opettajaryhmät eivät ole todellisuudessa olleetkaan eksperttejä ja noviiseja. Kokemus ja eksperttiys eivät välttämättä yhdisty muillakaan aloilla. Esimerkiksi Berlinerin käsityksen mukaan vain pieni osa, ehkä 10-15 prosenttia, opettajista kehittyy eksperttiyden tasolle (Berliner, suullinen tieto, syyskuu 1990). Suurin osa opettajista jää taitavan ja osaavan suorittajan tasoille, mitkä tasot sinänsä johtavat hyviin opetustuloksiin.

Toinen näkökulma siitä, missä määrin opettajat työssään asettuvat ja joutuvat asettumaan uusien haasteiden alle, liittyy myös eks. perttiyden kehittymiseen. Kehitystähän voidaan ajatella tapahtuvan vain niin kauan kuin yksilö joutuu alttiiksi tilanteille, joita hän ei entisellä tietämyksellään pysty välittömästi ratkaisemaan. Tämän kysymyksen piiri on laaja ja vaatii pohtimaan koulujärjestelmän luonnetta ja toimintaa nimenomaan opettajan kannalta. Onko tämänhetkinen opettajan työn sisältö sellainen, että se mahdollistaa optimaalisen ammattitaidon kehityksen työssä ? Michael Applen ym. (Apple ym. 1990) mukaan monet seikat viittaavat siihen, että opettajan työn luonne on muuttunut viimeisten vuosikymmenien aikana ammatillisen kehityksen kannalta huonompaan suuntaan. Työn sisällön yksipuolistuminen ja köyhtyminen, mahdollisuuksien väheneminen hallita omaa työtä kokonaisuutena ja työn intensiteetin ja määrän kasvu ovat heikentäneet mahdollisuuksia ja haluja vastata uusiin haasteisiin. Monilla ammatin. harjoittajilla opettamisen käytäntö on aidan matalimman kohdan etsimistä siksi, ettei resursseja riitä muuhun.

Edelleen voidaan löydettyjen erojen luonteesta todeta, etteivät ekspertit ja noviisit ole sisäisesti yhtenäisiä ryhmiä, vaan eroja löytyy runsaasti ryhmien sisältä. Ei liene paikallaan olettaakaan, että ekspertit tai noviisit olisivat samanlaisia esimerkiksi joidenkin toimintamenetelmien tai käyttäytymisen suhteen. Eksperttiyden on pikemminkin ajateltava olevan yksilön tietämykseen liittyvä ominaisuus, joka aikaansaa eksperteissä joustavuutta, informaation nopeampaa tulkintaa, ongelmien ja tilanteiden syvällisempää hahmottamista jne. Näin ollen eksperttiystutkimus ei voi eikä pyri anta. maan mitään 'hyvän' opettajan toimintamallia, ellei sellaisena sitten pidetä niitä ominaisuuksia, joiden suhteen eksperttien ja noviisien on edellä todettu eroavan toisistaan.

Tutkimukset osoittavat, että tietämyksen rakenteen ja laadun suhteen ekspertti- ja noviisi- 
opettajia voidaan kuvata tietyillä yleisillä ominaisuuksilla, mutta jäljelle jää erittäin paljon ominaisuuksia, joiden suhteen on turhaa edes yrittää etsiä samanlaisuuksia ryhmien sisältä.

Tulevaa eksperttiystutkimusta on suunnattava entistä enemmän sen kehittymisen prosesseihin. On tärkeää esimerkiksi tietää, millaiset opettajien perus- ja täydennyskoulutukseen tai työn sisältöön liittyvät uudistukset ovat tarpeen eksperttiyskehityksen saattamiseksi hyvään alkuun jo peruskoulutuksessa ja mahdollistamiseksi myöhemmin työssä. Eksperttiy. den tutkimus on tähän asti tarkastellut eroja kokeneiden ja aloittelevien välillä. Kuitenkin prosessit, jotka ovat johtaneet erojen syntymiseen ovat pääosin tuntemattomia.

\section{LÄHTEET}

Apple, M.W. \& Jungck, S. (1990) 'You don't have to be a teacher to teach this unit:" Teaching, technology, and gender in the classroom. American Educational Research Journal, 27(2), 227-251.

Berliner, D.C. (1988) Implications of studies of expertise in pedagogy for teacher education and evaluation. Teoksessa New directions for teacher assessment. Proceedings of the 1988 ETS Invitational Conference. NJ: Educational Testing Service.

Berliner, D.C. (1990). Characteristics of experts in the pedagogical domain. Paper presented at the International Symposium: Research on Effective and Responsible Teaching. Unversity of Fribourg, Fribourg, Switzerland. September 3-7.1990.

Calderhead, J. (1983). Research into teachers' and student teachers' cognitions: Exploring the nature of classroom practice. Paper presented at the annual meeting of the American Educational Research Association, Montreal.

Chi, M.T.H., Feltovich, P.J., Glaser, R. (1981). Categorization and representation of physics problems by experts and novices. Cognitive Science, 5(2), 121-152.

Chi, M.T.H., Glaser, R. \& Farr, M.J. (toim.) (1988). The nature of expertise. Hillsdale, $\mathrm{Nj}$ : Erlbaum

Chi, M.T.H., Glaser, R. \& Rees, E. (1982). Expertise in problem-solving. Teoksessa R.J. Sternberg (toim.) Advances in the psychology of human intelligence (Vol. 1). Hillsdale, N.J.: Erlbaum.

Dreyfus, H.L. \& Dreyfus, S.E. (1986). Mind over machine. New York: Free Press.

de Groot, A.D. (1965). Thought and choice in chess. The Haque: Mouton.

Glaser, R. (1976). Cognitive psychology and instructional design. Teoksessa D. Klahr (toim.) Cognition and instruction (s. 303-315). Hillsdale, NJ: Erlbaum. Glaser, R. (1987). Thoughts on expertise. Teoksessa C. Schooler \& W. Schaie (toim.), Cognitive functioning and social structure over the life course. Norwood, NJ: Ablex.

Hanninen, G. (1983). Do experts exist in gifted education ? Unpublished manuscript, University of Arizona, College of Education.

Housner, L.D., \& Griffey, D.C. (1985). Teacher cognition: Differences in planning and interactive decision making between experienced and inexperienced teachers. Research Quarterly for Exercise and Sport, 56, 44-53.

Kennedy, M.M. (1987). Inexact sciences: Professional education and the development of expertise. In E. Z. Rothkopf (Ed.), Review of Research in Education, Vol. 14. (pp. 133-167.), Washington, DC: American Educational Research Association.
Leinhardt, G. (1983). Novice and expert knowledge of individual student's achievement. Educational Psychologist, 18(3), 165-179.

Leinhardt, G. (1987). Development of an expert explanation: An analysis of a sequence of subtraction lessons. Cognition and Instruction, 4(4), 225-282.

Leinhardt, G. (1988). Situated knowledge and expertise in teaching. Teoksessa J. Calderhead (toim.), Teachers' professional learning (s. 146-168). London: Falmer Press.

Leinhardt, G. \& Greeno, J.G. (1986) The cognitive skill of teaching. Journal of Educational Psychology, 78, 2, 7595.

Nelson, K.R. (1988). Thinking processes, management routines and student perceptions of expert and novice physical education teachers. Unpublished dissertation, Louisiana State University, Baton Rouge, LA.

Peterson, P.L., Comeaux, M.A. (1987). Teachers' schemata for classroom events: The mental scaffolding of teachers' thinking during classroom instruction. Teaching and Teacher Education, 3, 319-331.

Ropo, E. (1987). Teachers' Conceptions of Teaching and Teaching Behavior: Some Differences between Expert and Novice Teachers. Paper presented at the Annual Meeting of the American Educational Research Association, Washington, D.C., April.

Ropo, E. (1990a). Teachers' questions: Some differences between experienced and novice teachers. Teoksessa H. Mandl, E. De Corte, N. Bennett \& H.F. Friedrich (toim.) Learning and instruction. European research in an international context. Vol. 2.2, s. 113-128. Pergamon Press.

Ropo, E. (1990b). What teachers know about their students: Some differences between experienced and novice elementary school teachers. Paper presented at the Conference of Effective and Responsible Teaching, Fribourg, Switzerland, September 3-7.

Ropo, E. (1990c). Expert and novice teaching: Differences in the lessons of experienced and novice English teachers. Teoksessa M. Carretero ym. (toim.) Learning and instruction. European research in an international context. Vol. 3. Pergamon Press (painossa).

Voss, J.F., Greene, T.R., Post, T.A., \& Penner, B.C. (1983). Problem-solving skill in the social sciences. Teoksessa G.H. Bower (toim.) The psychology of learning and motivation: Advances in research theory. Vol. 17, 165-213. NY: Academic Press. 


\section{AIKUISKASVATUS}

The Finnish Journal of Adult Education

Vol. 11, 3/91

ISSN 0358-6197

Summary

Ropo Eero 1991. Opettajaeksperttiyden kehittyminen - tutkimustuloksia ja näkökulmia. - Eksperttiyden olemusta koskeva tutkimus alkoi 1960-luvulla. Sen jälkeen eksperttiyttä on tarkasteltu monilla ammattialoilla. Opettajien eksperttiystutkimuksen käynnistäjä on Pittsburgin yliopistossa työskentelevä Gaea Leinhardt, joka on jaotellut eksperttiyden viiteen asteeseen. Artikkelissa käsitellään eksperttiyden kehittymisen peruspiirteitä yhdeksän väittämän pohjalta. Artikkelin mukaan eksperttiyden tutkimus on tähän asti tarkastellut eroja kokeneiden ja aloittelevien välillä. Kuitenkin prosessit, jotka ovat johtaneet ero-jen syntymiseen, ovat pääosin tuntemattomia. Aikuiskasvatus 11,3.
Ropo Eero 1991. The developmet of teacher expertise - research findings and points of view.

- Research on the subject of expertise began in the 1960s. Since then it has been examined in several occupational sectors. Gaea Leinhardt, a researcher at hte University of Pittsburgh, USA, initiated research on expertise and divided it into five levels. With nine theorems as the basis, the article deals with the fundamental aspects of the development of expertise. According to the author, research on expertise has so far been directed at differences between those who are experienced and those who are novices. Nevertheless, the processes that have led to these differences are largely unknown.

Aikuiskasvatus 11,3. 